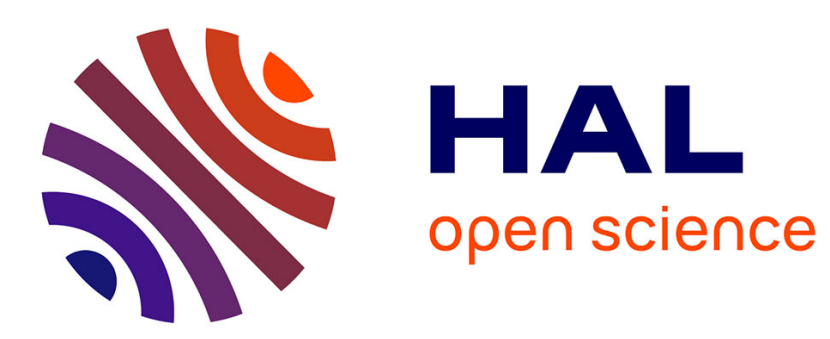

\title{
THE FUTURE OF NANOTECHNOLOGIES
}

Vincent Mangematin, Steve Walsh

\section{- To cite this version:}

Vincent Mangematin, Steve Walsh. THE FUTURE OF NANOTECHNOLOGIES. Technovation, 2012, 32 (3-4), pp.157-160. 10.1016/j.technovation.2012.01.003 . hal-00658034

\section{HAL Id: hal-00658034 \\ http://hal.grenoble-em.com/hal-00658034}

Submitted on 9 Jan 2012

HAL is a multi-disciplinary open access archive for the deposit and dissemination of scientific research documents, whether they are published or not. The documents may come from teaching and research institutions in France or abroad, or from public or private research centers.
L'archive ouverte pluridisciplinaire HAL, est destinée au dépôt et à la diffusion de documents scientifiques de niveau recherche, publiés ou non, émanant des établissements d'enseignement et de recherche français ou étrangers, des laboratoires publics ou privés. 


\title{
THE FUTURE OF NANOTECHNOLOGIES
}

\section{Vincent Mangematin ${ }^{1}$, Steve Walsh ${ }^{2}$}

${ }^{1}$ Grenoble Ecole de Management, 12 rue Pierre Semard, 38003 Grenoble Cedex France

${ }^{2}$ University of New Mexico, Anderson School of Management, Regents Professor

\begin{abstract}
Nanotechnology is the first major worldwide research initiative of the 21st century. Nanotechnologies are applied to cross industrial problems and are a general purpose technology that acts as both a basis for technology solutions or at the convergence of other enabling technologies, like biotechnologies, computational sciences, physical sciences, communication technologies, cognitive sciences, social psychology and other social sciences. Nanotechnologies are pervasive solution vectors in our economic environment. It is necessary to develop new methods to assess nanotechnologies development to better understand nanotechnology based innovation. As general purpose and enabling technologies, nanotechnologies reveal commercialization processes, from start-ups to large firms in collaboration with public sector research, and which lead to changing patterns of industrial organization which influence public policy initiatives to foster their development.
\end{abstract}

Keywords: Nanotechnology; general purpose technology; pan-industrial; convergence; hybridization; commercialization 
The aim of this introductory paper is to present a state-of-the-art synthesis of current thinking about the management of nanotechnologies. As general purpose and enabling technologies, nanotechnologies promise to make far-reaching changes in how technologies are evaluated, how they relate to industrial organization and how such on-going transformations should be understood. Anticipating the future, it seems that nanotechnologies' generalized diffusion will turn them into commodities, creating more space for dedicated, higher added value applications such as nanobiotechnologies, nanoenergy or nanomaterials.

Nanotechnology is the first major worldwide research initiative of the 21 st century. Nanotechnologies are general purpose technologies that act as both the basis for technology solutions across a range of industrial problems or as a nexus for the convergence of other enabling technologies like biotechnologies, computational sciences, physical sciences, communication technologies, cognitive sciences, social psychology and other social sciences (Freitas Jr, 2010; Hyungsub et al., 2009; Kautt et al., 2007; Linton et al., 2004). As for sustainability (Linton et al., 2007), the cross-industry and convergent nature of nanotechnology-based solutions promises to transform nearly every aspect of life (Compano et al., 2006, Tierney, 2011 \#10816; Loveridge et al., 2008; Malanowski et al., 2007) - for instance, via having opened the door to engineering at the molecular level (Drexler, 1986a; Walsh, 2004). Some see nanotechnologies as a field on their own, while others see their value in enabling a general trend of miniaturization in all physical technologies: either way, it is widely assumed that they will be pervasive solution vectors in our future economic environment. Applications employing nanotechnologies promise greater and more equal access to knowledge and information; new therapeutic interventions; improved environmental monitoring; greater safety and security; expanded communication capacities and many other industrial and societal applications. The enabling cross-industrial technology base (Fynman, 1960) they provide is being increasingly incorporated into existing products or processes to 
optimize production processes and produce better products with enhanced characteristics. In commercial terms, customers and users are only aware of nanotechnology-enabled products via their greatly increased functionality - in physically terms, individual nanotechnologies are invisible to the human eye. Their physical characteristics vary greatly from those of their macro counterparts, significantly affecting their internal design, their manufacture and their functionalities. The commercial promise of nanotechnology - as both the general foundation for and specific enabler of new innovations - makes it likely to underpin the next Schumpeterian wave of economic development (Wonglimpiyara, 2005) and its commercial promises has been formulated around its potential for facilitating such transformations (Selin, 2007).

\section{From breakthrough discoveries to general purpose technologies}

This technology base was first discussed in the last half of the $20^{\text {th }}$ century technically by (Fynman, 1960) and commercially by Drexler (Drexler, 1986b) and took decades to generate significant public investment. Huge public investments to support scientific and technological researches (Shapira et al., 2011; Teece, 2011), the creation of technological and industrial platforms and infrastructures (mainly in the $21^{\text {st }}$ century) have led to more than 2,000,000 articles related to nanotechnologies being published, and over 1,000,000 applications lodged with patent offices (Mangematin et al., 2012; Youtie et al., 2008b). Yet a significant question remains: To what extent does recent empirical evidence match the technologies' initial promises? Are nanotechnologies the next 'Schumpeterian Wave' which will revolutionize many industry sectors? Will they bring radical change to many scientific and technological fields, converging previously distinct technology-driven sectors in ways that will benefit economies and consumers alike (Allarakhia et al., 2011; Linton et al., 2008)? Or is it all just hype designed to mobilize energy and to renew investments in existing fields (Grodal, 2010)? 
Current nanotechnology developments have been successful up to a point: products incorporating nanotechnology based devices are on the markets, start-ups have been created and large firms have invested in production capacities (Fiedler et al., 2010, , 2011; Groen et al., 2008; Huang et al., 2011; Newbert et al., 2007; Palmberg, 2008). Nanoscience and Nanotechnology research is rapidly advancing, the rate of growth of the scientific production remains up to $10 \%$ per year, and nanotechnology based product innovations are increasing; Nanotechnologies are general purpose technologies (Gambardella et al., 2010). This is the reason why they are the objects of significant investments by incumbents (Rothaermel et al., 2007). So nanotechnologies are emerging, although the processes involved different from those that characterized the birth of the biotechnologies. Their pan-industry nature is illustrated not just through the adoption of nano-product paradigms - such as materials, devices, systems and components - but also by their ability to change industries radically - or even to create such new sectors as nanobiotechnologies (Allarakhia et al., 2011; Kuzma et al., 2010), nano-energy (Ying et al., 2010), nano-materials, nano- chemistry or nanoelectronics (Lee et al., 2007). Some sort of convergence is showing, with the emergence of nano-engines, new diagnostic tools hybridizing nanoelectronics and biotechnologies.

Nanotechnology has been seen as critical to $21^{\text {st }}$ century scientific advancement, technology development, product innovation, and social innovation. The century's problems have been seen as convergent, and their solutions as likely to require emerging technologies that create new product paradigms at the interfaces with other technologies (Nikulainen et al.). Some futurists consider nanotechnologies to be the foundation of the world's next economy, but our commercial and social understanding of the implications of the phenomena lags behind our scientific appreciation of its possibilities (Islam et al., 2010). This special issue advances our knowledge both about the foundations and the likely effects of nanotechnology. 


\section{Understanding the future of nanotechnologies}

Nine scholarly works contribute to our understanding of nanotechnology based innovation.

\section{New methodologies}

The first two papers propose new methodologies for evaluating nanotechnologies: An Chin Cheng (Chin cheng, 2012) has improved the field by developing a valuation methodology for the selection of new materials technology. He utilizes the 'fuzzy AHP' method to obtain the opinions of professionals and showed that, amongst seven evaluation criteria, 'data validity' has the highest weighting, followed by 'method adaptability' and 'technology development evaluability'. He concludes that the 'real options' approach and income methods are the two most applicable methods for evaluating new materials development. Wang Chunhsien (Chunhsien, 2012) discusses and evaluates the commercialization performance of nanoproducts from consumer perspectives. He constructs a series of nanoproducts' importance attributes and performance evaluation maps to identify areas for improvement. These evaluation methods are not dedicated to nanotechnologies even if they were developed for nanotechnologies they promise to be useful for other technology inquires as well.

\section{Value creation}

Our special issue furthers our understanding of nanotechnology commercialization with two studies. The first, based on 12 case studies of new ventures, Maine et al. (Maine, 2012) examine how firms create value from nanotechnologies, and show that firms exploiting nanotechnology based process innovation face greater uncertainty in their value chain positioning, market breadth, customization, and require more changes of their customers 
compared to more often studied product-based ventures (Cohendet et al., 2009; Packalen, 2007). They also show that nanotechnology ventures benefit from prioritizing technologymarket matching, alliance building and experimenting with technologies in new value networks. The second study in this section - by Juanola-Feliu et al. (Juanola-Feliu, 2012) develops our understanding of nanotechnology based diagnostics through an in depth review of a cutting-edge biomedical device for continuous in-vivo glucose monitoring, which is made possible by the convergence of medicine, physics, chemistry, biology, telecommunications, and electronics and energy researches. The paper traces how the process of commercializing the device required the alignment of a variety of different stakeholders University, Hospital, Industry, Administration and society. Both of these works progress the knowledge of nanotechnology commercialization by revealing different commercialization processes, from start-ups to large firms in collaboration with public sector research.

\section{Changing patterns of industrial organization}

Three papers analyze the changing patterns of industrial organizations in nanotechnologies (Jiang et al., 2011; Munari et al., 2011). First, Genet et al. (Genet, 2012) examine the patterns of technology transfer in nanotechnology. They compare the biotech technology transfer model - where start-ups and small firms bridged the collaborations between large firms and universities - with the technology transfer processes used in microelectronics to illustrate the differences between them and the nanotechnology transfer model. For example, while SMEs played valuable technology-bridging roles in the emergence of the biotechnologies and the central function of 'translating' new knowledge between public research and industry in technologies is carried by the larger firms, as it was in microelectronics, with SMEs playing the role of specialized providers. These results echo those recently published on US data (Thursby et al., 2011), and suggest that patterns of collaborations are context specific (Fiedler et al., 2010). Allarakhia and Walsh (Allarakhia et 
$a l ., 2012$ ) propose a method to manage, select, analyze and design large consortia which are central to commercial progress in nano-technology fields. They present a diagnostic tool to assess consortia centered on the technologies' commercial promise, adapting Institutional Analysis Development (IAD) to integrate nanotechnology innovators as well as their stakeholders (governments, industries, large firms, SME, entrepreneurial enterprises and supporting firms). von Raesfeld et al. (von Raesfeld, 2012) examine the determinants of the potential collaboration project performances in the Netherlands, by assessing the commercial performance of 169 nanotechnology research projects five years after their completion. She shows the strong positive impact of participants' skills complementarity, commitment and technological experience on both the projects' invention and financial performance, suggesting that project-based organization favors the hybridization of complementary competencies (Avenel et al., 2007; Bonaccorsi et al., 2007).

Finally, we have two papers which further the discussion of public policy initiatives to foster nanotechnology developments. Battard (Battard, 2012) discusses the formation of nanocenters and argues that research groups dedicated to nanotechnology are technological hubs where scientists with multiple backgrounds converge in order to conduct research at the nanoscale. These hubs inherit from established scientific disciplines, but create local practices and knowledge, and their multidisciplinary context and the absence of standards can create misalignment for junior scientists between their initial discipline, their research and the outcomes they are expected to produce. Battard's analysis questions the emergence of nanotechnology as a discipline, as most scientists remain closely linked to their original disciplines. Battard's observation at the micro-level is confirmed by Baglieri et al. (Baglieri et $a l .$, 2012). Nanotechnologies are developed by a small number of large clusters worldwide (Grimpe et al., 2011; Mangematin et al., 2012; Meyer et al., 2011; Robinson et al., 2007; Youtie et al., 2008b). Comparing two nano-electronics clusters - Grenoble (France) and 
Catania (Italy) - the authors emphasize the role of scientific and technological diversity, competition for cluster orchestration and overlap between networks in stimulating cluster evolution. They point out that competition to orchestrate clusters stimulates 'sleeping anchor' tenants to influence cluster research avenues, and shape new networks within and beyond its boundaries. Cluster evolution is based on hybridization with existing technological fields that using nanotechnologies, such as nano-energy or nano biotechnology. (Kajikawa et al., 2010).

\section{The paradox of nanotechnologies}

Since Drexler (1986) who introduce the term nanotechnologies and the development of the first critical nanotechnology roadmaps (Bozeman et al., 2007; Walsh, 2004), the deployment of nanotechnologies has become clearer. Incumbents play the central roles (Allarakhia et al., 2011; Jiang et al., 2011; Mangematin et al., 2011), with start-ups and SMEs acting as specialized suppliers while large firms and public sector research organizations form direct alliances to develop and to market nanotechnologies. Nanotechnology-based devices are incorporated in existing products and embedded in production processes. Convergence or hybridization is very progressive, leading to the design of new products that merge two or three different bodies of technologies. Scientific convergence appears to be slower than the integration of nanotechnologies in existing or new products or processes. New centers have been created to host the different scientists working at the nanoscale level (Kautt et al., 2007), and new scientific communities have emerged building on existing disciplines but using new techniques and facing new problems. These activities confirm the sense of nanotechnologies as general purpose technologies which impact a wide range of scientific and technological fields and change how research and production processes are performed. As Arora and Gambardella (Arora, 1994) have pointed out in biotechnology, nanotechnologies are changing 
the "technology of technological change", but affecting different scientific fields and different industries.

Paraphrasing Solow's paradox about computers, we can say that nanotechnologies are found everywhere except as a new industry or a new scientific field. Anderson (Andersen, 2011) emphasizes silent innovation; Battard describes new nanotechnology centers as technological hubs; Genet et al. underline how nanotechnology technology transfer mechanisms resemble those in microelectronics. Industrial organization appears not to be specific either (Jiang et al., 2011; Mangematin et al., 2011; Youtie et al., 2008a) - start-ups and small firms are created as specialized suppliers since (as Maine et al. (Maine, 2012) as point out) the market is large enough to accommodate niche sectors, while alliances and collaborations appear to reproduce their patterns in microelectronics and biotechnologies, involving different actors in creating, manufacturing and commercializing complex products and services.

This special issue has two blind spots. First, questions of regulation and societal acceptance of nanotechnologies remain important issues to explore. The Technovation special issue on "the future of nanotechnologies" does not address the evolution of institutions and the interplay between acceptance, strategies and the formation of markets (Allan et al., 2010; Throne-Holst et al., 2008; Yawson et al., 2010). Second, nanotechnologies are not only general purpose technologies - they are also technologies that enable the creation of new devices and new ways to improve the quality of life. Nanotechnologies are embedded in existing industries and research using nanotechnologies are developed within existing fields, transforming them from microelectronics to nano-electronics, from biotechnologies to nanobiotechnologies, and from energy to nano energy. Firms are exploring new ways to address consumer needs, new business models based on the changes nanotechnologies could enable in existing industries. The multiplication of competing business models may transform industry 
logics, as it has been the case for the music industry or for digital photography (Bettis et al., 1995; Munir, 2005; Sabatier et al., 2011). What sort of transformations can we expect? What dominant logics will be challenged and in which industries? Such questions open room for new research.

\section{REFERENCES}

Allan S, Anderson A, Petersen A. 2010. Framing risk: nanotechnologies in the news. Journal of Risk Research 13(1): 29-44

Allarakhia M, Walsh S. 2011. Managing knowledge assets under conditions of radical change: The case of the pharmaceutical industry. Technovation 31(2/3): 105-117

Allarakhia M, Walsh S. 2012. Analyzing and Organizing Nanotechnology Development: Application of the Institutional Analysis Development Framework To Nanotechnology Consortia Technovation 32(2)

Andersen MM. 2011. Silent innovation: corporate strategizing in early nanotechnology evolution. The Journal of Technology Transfer 36(6): 680-696

Arora A, Gambardella, A. 1994. The changing technology of technological change : general and abstract knowledge and the division of innovative labour. Research Policy 23: 523-532

Avenel E, Favier AV, Ma S, Mangematin V, Rieu C. 2007. Diversification and hybridization in firm knowledge bases in nanotechnologies. Research Policy 36(6): 864-871

Baglieri D, Cinici MC, Mangematin V. 2012. Rejuvenating Clusters with Sleeping Anchors: the Case of Nanoclusters". Technovation 32(2)

Battard N. 2012. Convergence and Multidisciplinarity in Nanotechnology: Laboratories as Technological Hubs. Technovation 32(2)

Bettis R, Prahalad C. 1995. The Dominant Logic: Retrospective and Extension. . Strategic Management Journal 16(1): 5-14

Bonaccorsi A, Thoma G. 2007. Institutional Complementarity and Inventive Performance in Nano Science and Technology. Research Policy 36(6): 813-831

Bozeman B, Laredo P, Mangematin V. 2007. Understanding the Emergence and Deployment of 'Nano' S\&T: Introduction. Research Policy 36(6): 807-812

Chin cheng A. 2012. A fuzzy multiple criteria comparison of technology valuation methods for the new materials development Technovation 32(2)

Chunhsien W. 2012. An Empirical Study of Commercialization Performance on Nanoproducts. Technovation 32(2)

Cohendet P, Pawlak E. 2009. Diversity of entrepreneurs and diversity of clusters in nanotechnologies. International Journal of Technology Management 46(3/4): 386-403

Compano R, et al. 2006. Converging Applications for Active Ageing Policy. Foresight 8(2): 30- 
Drexler KE. 1986a. The engine of Creation. MIT Press: Cambridge, Massachusetts

Drexler KE. 1986b. Engines of Creation: The Coming Era of Nanotechnology. . Anchor Doubleday: New York, NY.

Fiedler M, Welpe IM. 2010. Antecedents of cooperative commercialisation strategies of nanotechnology firms. Research Policy 39(3): 400-410

Fiedler M, Welpe IM. 2011. Commercialisation of technology innovations: an empirical study on the influence of clusters and innovation networks. International Journal of Technology Management 55(1): 410-437

Freitas Jr RA. 2010. The Future of Nanomedicine. Futurist 44(1): 21-22

Fynman R. 1960. There's Plenty of Room at the Bottom. . Engineering and Science 23: 22-36

Gambardella A, McGahan A. 2010. Business-Model Innovation: General Purpose Technologies and their Implications for Industry Structure. Long Range Planning 43(2)

Genet CE, Khalid; Gauthier, Caroline 2012. Which Model of Technology Transfer for Nanotechnology? A Comparison with Biotech and Microelectronics Technovation 32(2)

Grimpe C, Patuelli R. 2011. Regional knowledge production in nanomaterials: a spatial filtering approach. Annals of Regional Science 46(3): 519-541

Grodal S. 2010. Meaning Machanisms in Nanotechnology: The expansion and Contraction of Field Labels. In AoM (Ed.), Academy of Management: Montreal

Groen AJ, Van Der Sijde P, Walsh S. 2008. Guest Editors' Introduction: Entrepreneurship's Role in Commercializing Disruptive Technologies. International Small Business Journal 26(1): 5-7

Huang L, Guo Y, Peng Z, Porter AL. 2011. Characterising a technology development at the stage of early emerging applications: nanomaterial-enhanced biosensors. Technology Analysis \& Strategic Management 23(5): 527-544

Hyungsub C, Mody CCM. 2009. The Long History of Molecular Electronics: Microelectronics Origins of Nanotechnology. Social Studies of Science (Sage) 39(1): 11-50

Islam N, Miyazaki M. 2010. An Empirical Analysis of Nanotechnology Research domains. Technovation 30(4): 229-237

Jiang L, Tan J, Thursby M. 2011. Incumbent firm invention in emerging fields: evidence from the semiconductor industry. Strategic Management Journal 32(1): 55-75

Juanola-Feliu EC-F, Jordi; Miribel-Català, Pere; Samitier, Josep; Valls-Pasola, Jaume 2012. Market challenges facing academic research in commercializing nano-enabled implantable devices for in-vivo biomedical analysis. Technovation 32(2)

Kajikawa Y, Takeda Y, Sakata I, Matsushima K. 2010. Multiscale analysis of interfirm networks in regional clusters. Technovation 30: 168-180

Kautt M, Walsh S, Bittner K. 2007. Global distribution of micro-nano technology and fabrication centers: A portfolio analysis approach. Technology Forecasting and Social Change 74: 1697-1717.

Kuzma J, Tanji T. 2010. Unpackaging synthetic biology: Identification of oversight policy problems and options. Regulation \& Governance 4(1): 92-112 
Lee YG, Song YI. 2007. Selecting the key research areas in nano-technology field using technology cluster analysis: A case study based on National R\&D Programs in South Korea. Technovation 27(1-2): 57-64

Linton JD, Klassen R, Jayaraman V. 2007. Sustainable supply chains: An introduction. Journal of Operations Management 25(6): 1075-1082

Linton JD, Walsh S. 2004. Integrating innovation and learning curve theory: An enabler for moving nanotechnologies and other emerging process technologies into production. R\&D Management 34: 513-522.

Linton JD, Walsh ST. 2008. A theory of innovation for process-based innovations such as nanotechnology Technological Forecasting and Social Change 75(5): 583-594

Loveridge D, Dewick P, Randles S. 2008. Converging technologies at the nanoscale: The making of a new world? Technology Analysis \& Strategic Management 20(1): 29-43

Maine EL, Sarah ; Garnsey, Elizabeth 2012. Process-Based vs. Product-Based Innovation: Value Creation by Nanotech Ventures. Technovation 32(2)

Malanowski N, Compano R. 2007. Combining ICT and Cognitive Science: Opportunities and Risks. Foresight 9(3): 18-29

Mangematin V, Errabi K. 2012. The Determinants of the science-based cluster growth: The case of Nanotechnologies. Environment and Planning C-Government and Policy forthcoming

Mangematin V, Errabi K, Gauthier C. 2011. Large players in the nanogame: Dedicated Nanotech Subsidiairies or Distributed Nanotech Capabilities? . The Journal of Technology Transfer 36(6): 640-664

Meyer M, Libaers D, Park J-H. 2011. The Emergence of Novel Science-related Fields: Regional or Technological Patterns? Exploration and Exploitation in United Kingdom Nanotechnology. Regional Studies 45(7): 935-959

Munari F, Toschi L. 2011. Do venture capitalists have a bias against investment in academic spin-offs? Evidence from the micro- and nanotechnology sector in the UK. Industrial \& Corporate Change 20(2): 397-432

Munir KA. 2005. The Social Construction of Events: A Study of Institutional Change in the Photographic Field. Organization Studies 26(1): 93-112

Newbert SL, Kirchhoff BA, Walsh ST. 2007. Defining the Relationship among Founding Resources, Strategies, and Performance in Technology-Intensive New Ventures: Evidence from the Semiconductor Silicon Industry. Journal of Small Business Management 45(4): 438-466

Nikulainen T, Palmberg C. Transferring science-based technologies to industry-Does nanotechnology make a difference? Technovation 30(1): 3-11.

Packalen KA. 2007. Complementing Capital: The Role of Status, Demographic Features, and Social Capital in Founding Teams' Abilities to Obtain Resources. Entrepreneurship: Theory \& Practice 31(6): 873-891

Palmberg C. 2008. The Transfer and Commercialisation of Nanotechnology: A Comparative Analysis of University and Company Researchers. Journal of Technology Transfer 33(6): 631-652

Robinson DKR, Rip A, Mangematin V. 2007. Technological agglomeration and the emergence of clusters and networks in nanotechnology. Research Policy 36(6): 871-879 
Rothaermel FT, Thursby M. 2007. The nanotech versus the biotech revolution: Sources of productivity in incumbent firm research. Research Policy 36(6): 832-849

Sabatier V, Kennard A, Mangematin V. 2011. Challenging a Dominant Industry Logic: Technological Discontinuities and Disruptive Business Models in the Drug Industries. Technological Forecasting and Social Change Forthcoming

Selin C. 2007. Expectations and the Emergence of Nanotechnology. Science, Technology \& Human Values 32(2): 196-220

Shapira P, Youtie J. 2011. Introduction to the symposium issue: nanotechnology innovation and policy-current strategies and future trajectories. The Journal of Technology Transfer 36(6): 581586

Teece D. 2011. Nanotechnology and the US national innovation system: continuity and change. The Journal of Technology Transfer 36(6): 697-711

Throne-Holst H, Sto E. 2008. Who Should Be Precautionary? Governance of Nanotechnology in the Risk Society. Technology Analysis and Strategic Management 20(1): 99-112

Thursby J, Thursby M. 2011. University-industry linkages in nanotechnology and biotechnology: evidence on collaborative patterns for new methods of inventing. The Journal of Technology Transfer 36(6): 605-623

von Raesfeld AG, Peter; Boshuizen, Johannes ; Jansen, Mark; Luttge, Regina 2012. Collaboration portfolios and outcomes of public R\&D projects. A study of economic value creation and utilization of nanotechnologies in the Netherlands Technovation 32(2)

Walsh S. 2004. Road mapping a disruptive technology: A case study-The emerging microsystems and top-down nanosystems Industry. Technological Forecasting and Social Change $71(161-185)$

Wonglimpiyara J. 2005. The nano-revolution of Schumpeter's Kondratieff cycle. Technovation 25: $1349-1354$

Yawson R, Kuzma J. 2010. Systems Mapping of Consumer Acceptance of Agrifood Nanotechnology. Journal of Consumer Policy 33(4): 299-322

Ying G, Lu H, Porter AL. 2010. The research profiling method applied to nano-enhanced, thinfilm solar cells. R\&D Management 40(2): 195-208

Youtie J, Iacopetta M, Graham S. 2008a. Assessing the Nature of Nanotechnology: Can We Uncover an Emerging General Purpose Technology? Journal of Technology Transfer 33(3): 315329

Youtie J, Shapira P. 2008b. Mapping the nanotechnology enterprise: a multi-indicator analysis of emerging nanodistricts in the US South. Journal of Technology Transfer 33(2): 209-223 